\title{
KURIKULUM PENDIDIKAN KESEHATAN DI SEKOLAH SEBAGAI UPAYA MENINGKATKAN KESADARAN HIDUP SEHAT SEJAK DINI
}

[Afifah Nasyahta Dila]

\section{OBJECTIVES}

Intervensi kesehatan terkait PHBS harus semakin berkembang terutama pada anak dan remaja selaku aset bangsa. Permasalahan perilaku tidak sehat terkait personal hygiene, kebiasaan sehat dan asupan gizi belum teratasi secara sempurna. Hal ini dapat dilihat melalui capaian PHBS tahun 2016 dan 2017 di SD, SMP dan SMA Kabupaten Lumajang sebagai berikut

Capaian PHBS Kabupaten Lumajang -2016 -2017 -Target

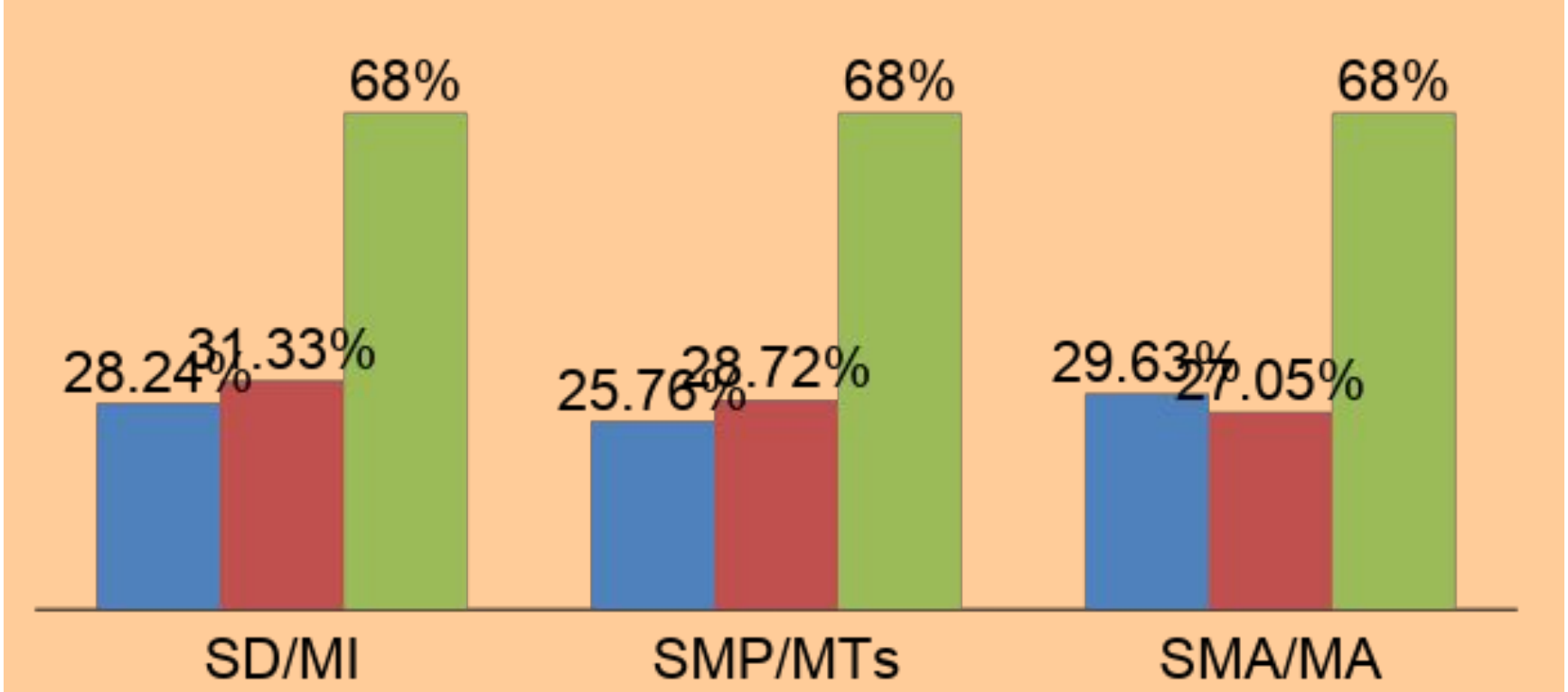

Dinas Kesehatan Kabupaten Lumajang berupaya mengatasi masalah PHBS dan merokok pada anak melalui program Buku Harian Anak Terhebat (BHAT). Namun program ini hanya menjangkau siswa kelas 4 dan 5 SD serta belum menentukan strategi sustainabilitas program dan pencapaian target.
Sedangkan masalah kesehatan bagi anak dan remaja semakin meluas. Kebiasaan merokok pesta miras, penyalahgunaan narkoba, perilaku seks bebas, balapan liar hingga penggunaan media sosial yang menyimpang merupaka ancaman bagi anak dan remaja di Kabupaten Lumajang. Pemerintah seharusnya mulai merancang intervensi kesehatan untuk mencegah perilaku menyimpang dan tidak sehat mencegah perilaku menyimpang dan tidak
di seluruh tingkat pendidikan di Lumajang.
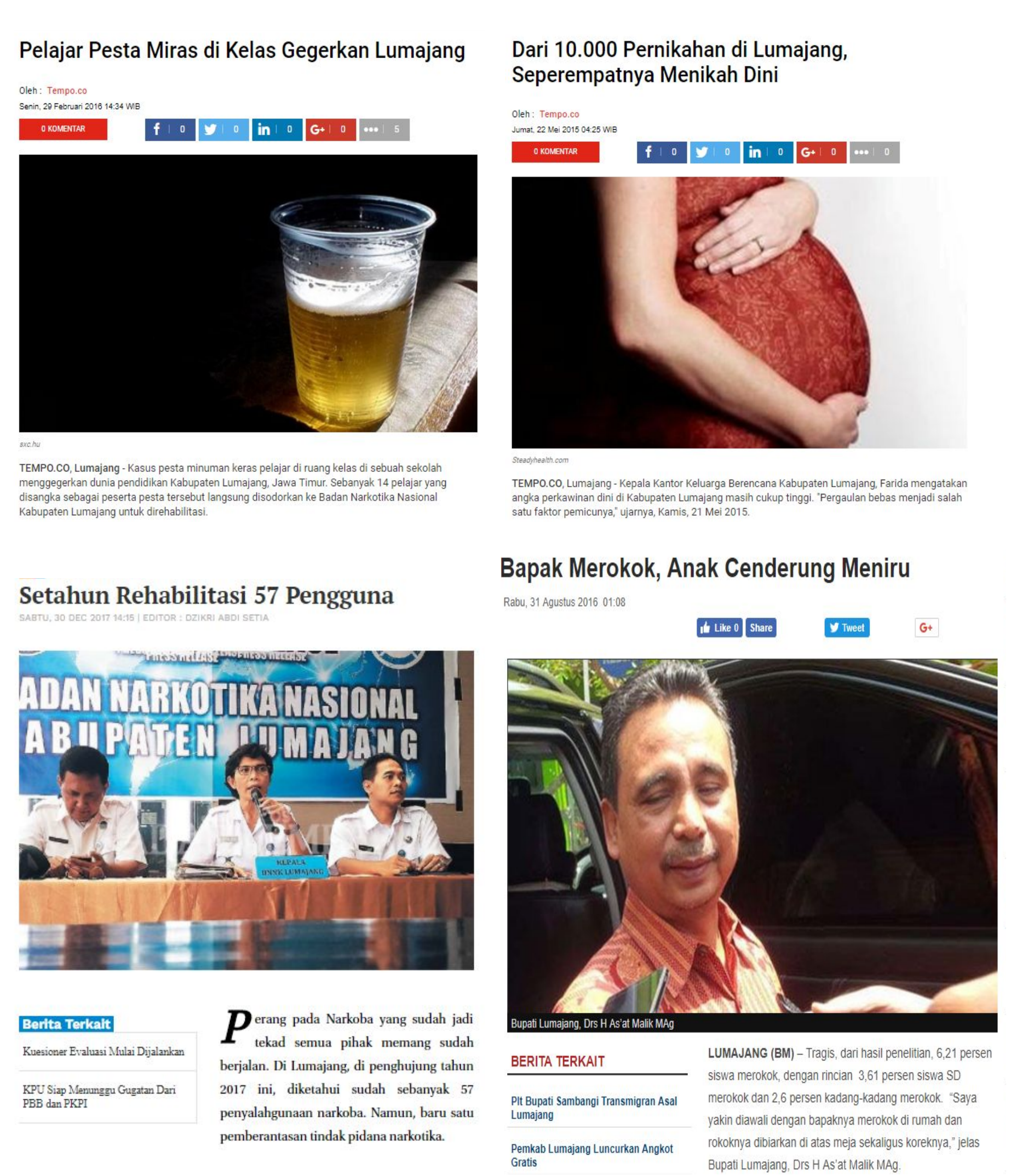

\section{LESSON LEARNED}

Salah satu upaya yang dapat dilakukan Pemerintah Kabupaten Lumajang untuk meningkatkan capaian PHBS sekaligus menciptakan kota ramah anak melalui pembentukan kurikulum pendidikan kesehatan. Pembentukan kurikulum pendidikan kesehatan merupakan salah satu poin penting dalam mensukseskan program sekolah sehat menurut WHO. Intensitas penyampaian intervensi kesehatan di sekolah mempengaruhi efektifitas dari pesan kesehatan, sehingga jika setiap minggu siswa menerima pendidikan kesehatan selama 1 jam pelajaran dan diberikan sejak tingkat SD hingga SMA maka upaya meningkatkan pengetahuan, sikap dan perilaku hidup bersih dan sehat sejak dini dapat tercapai secara sustainabilitas.

\section{RECOMMENDATIONS}

Pembuatan kurikulum pendidikan kesehatan membutuhkan kolaborasi lintas sektor. Beberapa hal yang bisa dilakukan Diinkes Lumajang yaitu

Melakukan lobbying kepada Bupati untuk mendapat persetujuan serta meminta dukungan lintas sektor

Dinas Pendidikan dan Kementerian agama merancang kurikulum pendidikan kesehatan di SD hingga SMA.

Dinas Kesehatan memberikan sosialisasi dan capacity building bagi Puskesmas dan sekolah terkait teknik penyuluhan kesehatan yang efektif kepada anak dan remaja.

\section{REFERENCES}

Agabio, R Trincas, G. Floris, F Mura, G Sancassiani, F. \& Angermeyer, M. C. (2015). A systematic review of school-based alcohol and other drug prevention programs. Clinical practice and epidemiology in mental health: CP \& EMH, 11(Suppl $1 \mathrm{M6}$ ), 102.

Anonim. (2016). Bapak Merokok, Anak Cenderung Meniru. Berita Metro. 31 Agustus 2016 http://www.beritametro.news/Lumajang/bapak-merokok-an ak-cenderung-meniru

angford, R., Bonell, C., Jones, H., Pouliou, T., Murphy, S. Waters, E., ... \& Campbell, R. (2015). The World Health Organization's Health Promoting Schools framework: a Cochrane systematic review and meta-analysis. BMC public health, 15(1), 130.

Priyasidharta, D. (2016). Pelajar Pesta Miras di Kelas Gegerkan Lumajang. Tempo. 29 Februari 2016. https://nasional.tempo.co/read/749161/pelajar-pesta-miras -di-kelas-gegerkan-lumajang

Priyasidharta, D. (2015). Dari 10.000 Pernikahan di Lumajang, Seperempatnya Menikah Dini. Tempo. $22 \mathrm{Me}$ 2015.

https://nasional.tempo.co/read/668350/dari-10-000-pernika han-di-lumajang-seperempatnya-menikah-dini

Setya, D.A. (2017). Setahun Rehabilitasi 57 Pengguna. $\begin{array}{llll}\text { Jawapos. } & 30 & \text { Desember } & 2017 .\end{array}$ https://www.jawapos.com/radarjember/read/2017/12/30/36 587/setahun-rehabilitasi-57-pengguna

Racey, M., O'Brien, C., Douglas, S., Marquez, O., Hendrie G., \& Newton, G. (2016). Systematic Review of School-Based Interventions to Modify Dietary Behavior: Does Intervention Intensity Impact Effectiveness?. Journal of School Health, 86(6), 452-463.

WHO (2015) Global School Health Initiatives: Achieving Health and Education Outcomes, Geneva: World Health Organization 